$$
\begin{gathered}
\text { UNIVERSITY OF CALIFORNIA } \\
\text { COLLEGE OF AGRICULTURE } \\
\text { AGRICULTURAL EXPERIMENT STATION } \\
\text { BERKELEY, CALIFORNIA }
\end{gathered}
$$

\title{
YIELD, STAND, AND VOLUME TABLES FOR WHITE FIR IN THE CALIFORNIA PINE REGION
}

FRANCIS X. SCHUMACHER

\section{BULLETIN 407}

OCTOBER, 1926 
Digitized by the Internet Archive in 2012 with funding from University of California, Davis Libraries 


\title{
YIELD, STAND AND VOLUME TABLES FOR WHITE FIR IN THE CALIFORNIA PINE REGION ${ }^{1}$
}

\author{
FRANCIS X. SCHUMACHER 2
}

\section{INTRODUCTION}

Facts concerning rate of growth and yields of the timber types to be found on a forest property (and such facts are among those of first importance for proper management of a forest) are best shown by what are known as yield tables. These tables express yields in volume, number of trees or logs, and size of tree, to be expected from stands over given periods of time.

The several types of the main timber belt of the California pine region are made up of one or more of five important species, viz.: western yellow pine (Pinus ponderosa Laws.), sugar pine (Pinus lambertiana Dougl.), Douglas fir (Pseudotsuga taxifolia Britt.), white fir (Abies concolor Lindl.), and incense cedar (Libocedrus decurrens Torr.). Near the upper altitudinal limits of the main timber belt, red fir (Abies magnifica Murr.) is also found. Western yellow pine, Douglas fir, and white fir occur in pure stands as well as in mixtures, while sugar pine and incense cedar are found in mixtures only.

A study of the growth of the mixed types may be more readily undertaken when the yields of those species which also occur pure are known. The United States Forest Service is at present conducting such studies in pure, even-aged stands of western yellow pine and Douglas fir. This bulletin presents the results of a similar study of the growth and yield of white fir.

\section{BASIC DATA}

The data upon which the tables are based are measurements of 157 normally stocked, even-aged sample plots of white fir, covering a range of age classes of from 40 to 150 years, and conditions of productivity as varied as could be found.

1 The writer is indebted to Mr. P. D. Hanson, Associate in Forestry, who helped in gathering a large part of the data and performed most of the computational work; to Mr. H. M. Siggins, Baker Research Assistant in Forestry, and to Professors W. Metcalf and E. Fritz, who assisted in gathering data; to Mr. D. Dunning of the U. S. Forest Service, who contributed available data from 51 white fir sample plots for the yield study and 600 white fir tree measurements as the basis for the volume tables. 


\section{Plot Selection:}

In virgin timber of the California pine region, even-aged stands occur when areas, denuded by accident (such as fire, insect depredations or disease epidemies), are seeded from neighboring timber which has a good seed crop. Such areas are not common and the irregularity of their accidental stocking is a factor that limits sample plot size.

An even-aged stand is here considered to be normally stocked when the tree growth seems to make full use of climatic and soil factors, so as to produce ideal volume for site and age, both in size of individual tree and total volume. An overstocked stand may produce greater volume to the acre than a normally stocked one, but dominant individual trees may become stunted from the crowding. Conversely, an understocked stand may produce larger individual trees at the expense of total volume.

In stands which seemed to contain normally stocked areas, plot boundaries were located so as to exclude the larger blanks caused by failure of reproduction or accident, thus enclosing a comparatively complete crown canopy. No attempt was made to lay out rectangular boundaries, although acute angles were avoided. Plots were surveyed with staff compass and chain.

\section{Age Determination:}

Age of each plot was obtained with Swedish increment borers by boring to the pith, near the base of several dominant trees and counting the annual rings on the extracted core, to which was added the necessary correction for height growth to the point of boring. The age of the oldest tree was taken as the age of the plot, provided it did not vary by a significant difference (arbitrarily set at six years) from the ages of the others. When variation exceeded six years, plots were not considered even-aged and were usually not taken.

\section{Field Measurements:}

Diameters breast-high of all trees 4 inches and over were measured with diameter tape and tallied by species and crown class, and sufficient heights (of 15-25 trees) for a height-diameter curve for each important species were obtained with a Forest Service hypsometer.

A short description of physiographic features completed the field work on each plot. 


\section{Office Computations:}

Number of trees, basal area, cubic volume and board-foot volume were computed by species, diameter, and crown class, and totaled for each plot. These figures were then calculated on the acre basis. Average height (i.e., height of tree of average basal area) was read from the height-diameter curve of each species on each plot (1) for all trees, (2) for trees 8 inches and over, and (3) for the dominant stand.

Volumes of individual trees were taken from volume tables for white fir. ${ }^{3}$ The cubic-foot volume is that of entire stem exclusive of bark. The board-foot volume is that between a 1-foot stump and top diameter (inside bark) of 5 inches, based on the International Log Rule, 1/8 inch kerf.

\section{SITE CLASSIFICATION}

Site quality is classified according to the height of the average dominant white fir at 50 years of age. Average height of the dominant stand at a given age is now generally accepted as the simplest and most convenient indicator of the wood-producing power of a forest area. But the standard classification of the range of the species into three or five sites is not used. Instead, each plot was assigned a site index or number corresponding to the height, in feet, that its average dominant white fir would attain (or had attained) at 50 years. With quality of site thus definitely bound up with a given height of dominant at a given age, a universal classification for all species of the region may be adopted, into which site qualities as here defined may readily be made to fit.

Figure 1 shows the height curves used in determining site classification. These curves were constructed by fitting a form curve showing increase in height of the average dominant for the average of all sites, and a series of curves of the same form passing through ten-foot height intervals at 50 years, thus defining site classes.

The form of the curves below 40 years of age was based on measurements of individual dominant trees instead of on the average dominant of plots, because no plots under 40 years of age with trees in the 4-inch diameter class (the minimum diameter tallied) or over, were found.

${ }^{3}$ Volume tables in both board-foot and cubic-foot units are given on pp. 24-26. 


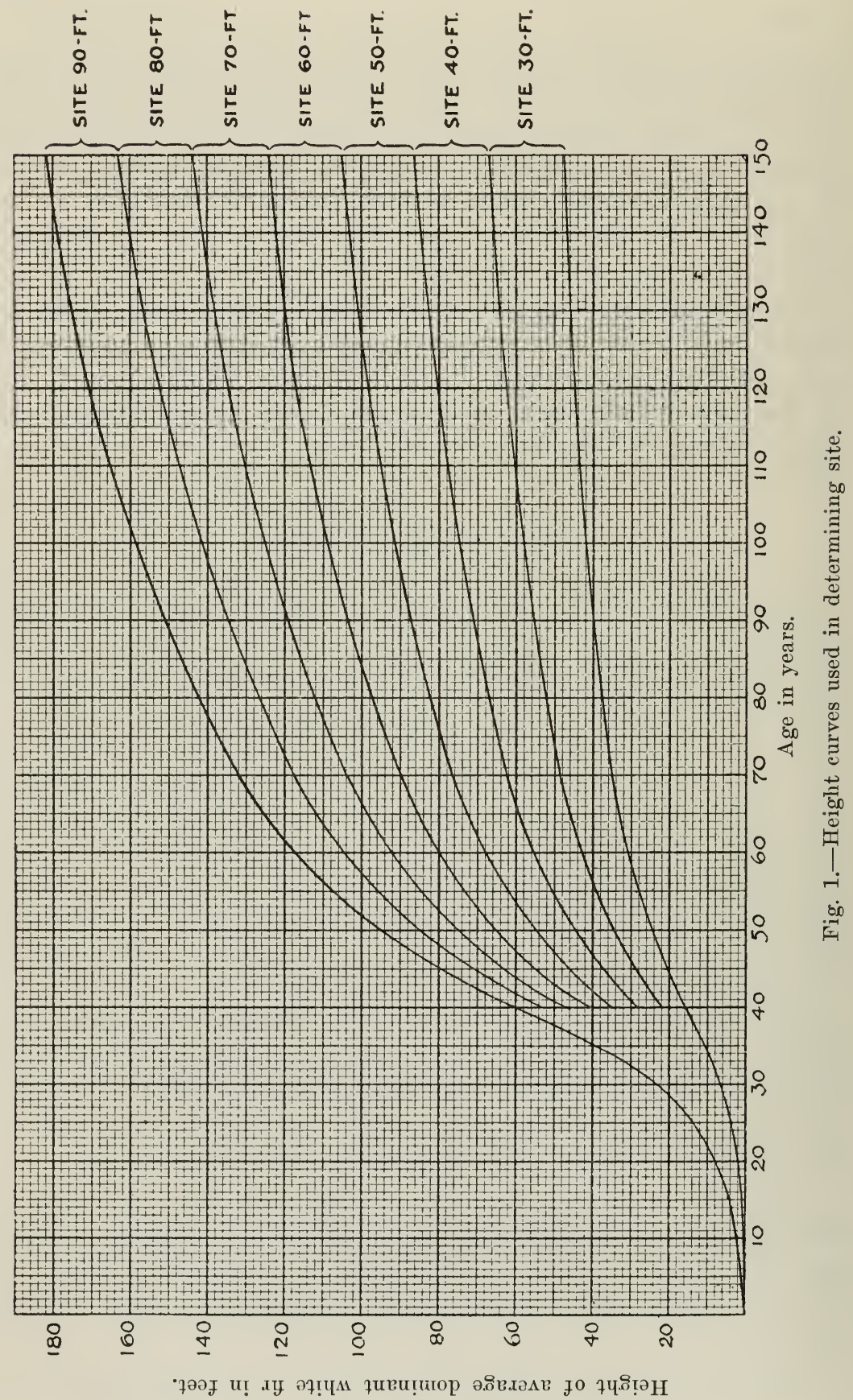




\section{YIELD TABLES}

Table 1 gives the following data for the stand 4 inches and over in diameter: the number of trees to the acre, average diameter breast high, average height, basal area in square feet and volume in cubic feet to the acre, and average annual growth in cubic feet, by site and age classes. Table 2 gives corresponding values for the stand 8 inches and over in diameter, except that volume and average annual growth is given in board measure, and a column is added giving log run to the thousand feet of board measure.

\section{DISTRIBUTION OF TREES BY DIAMETER CLASSES}

Table 1 gives the number of trees to the acre and average diameter for each site and age class, but does not indicate distribution of the number by diameter classes. Complete stand tables which show such distribution would require too much space here, as a separate table would be needed for each site-age class. Analysis indicates that the distribution of trees by diameter classes is primarily a function of average diameter, so that factors of site and age influence distribution insofar only as they affect average diameter of the stand and number of trees to the acre. A single stand table, then, showing distribution of trees in per cent of the total number, when average diameter of the stand is known (table 3), serves the purpose very well. ${ }^{4}$

Knowing average diameter of the stand and number of trees to the acre as given in table 1 , the number of trees by diameter classes may be readily computed by converting the percentages of table 3 into number of trees.

\section{EFFECT OF NUMBER OF TREES TO THE ACRE ON YIELD}

Natural stands which come in after logging, while essentially even-aged, are seldom fully stocked except on small portions of the area. But it is to be expected that as crowns of the individual trees grow and meet, forming a more or less complete crown canopy, such stands approach full stocking, not, perhaps, in number of trees to the acre for age and site, but in volume, because if the number of

\footnotetext{
* The method of constructing the stand table is explained on pp. 21-22.
} 
trees is deficient as compared with tables 1 and 2 , the diameter of individual trees should be greater. This is brought out in figure 2, which shows that when crown canopy is fairly complete, the number of trees which have board-foot contents (i.e., trees 8 inches and over in diameter breast high) may be but half the number given in table 2 , yet in volume board measure the stand should have between 65 and 70 per cent of that given in the table.

For example, suppose a 30-year-old stand of Site 80 feet has 200 well-spaced trees to the acre averaging perhaps 2 inches in diameter breast-high. It is safe to assume, provided the area is given protection, that none of these trees will die from crowding, so that when the stand becomes 90 years old, there should still be 200 trees to the acre, all over 8 inches in diameter breast high. Table 2 gives 249 merchantable trees for this age and site. The stand, then, will be 80 per cent stocked by number of trees, and according to figure 2, 87 per cent normal by volume board measure; that is, it should contain 87 per cent of 118,000 or 103,000 feet board measure.

It seems safe to assume, also, that at 120 years the area will still have 200 trees. By that time it should be normal according to table 2, both in number of trees and in volume.

TABLE 1

Normal Yield Table for White Fir, Including Trees 4 Inches and Over

\begin{tabular}{c|c|c|c|c|c|c|c}
\hline \hline Age & $\begin{array}{c}\text { Number } \\
\text { of Trees } \\
\text { per Acre }\end{array}$ & $\begin{array}{c}\text { Average } \\
\text { Height } \\
\text { of Trees }\end{array}$ & $\begin{array}{c}\text { Average } \\
\text { Diameter } \\
\text { Breast High }\end{array}$ & $\begin{array}{c}\text { Basal } \\
\text { Area per } \\
\text { Acre }\end{array}$ & $\begin{array}{c}\text { Volume } \\
\text { per Acre }\end{array}$ & $\begin{array}{c}\text { Average } \\
\text { Annual } \\
\text { Growth }\end{array}$ & $\begin{array}{c}\text { Basis } \\
\text { Number } \\
\text { of Plots }\end{array}$ \\
\hline Years & Feet & Inches & Square Feet & Cubic Feet & Cubic Feet & \\
\hline
\end{tabular}

Site index 90 feet at 50 years

\begin{tabular}{r|r|r|r|r|r|r|r}
\hline 50 & 437 & 75 & 11.5 & 316 & 9000 & 180 & 2 \\
60 & 376 & 93 & 13.6 & 381 & 12600 & 210 & 3 \\
70 & 326 & 104 & 15.5 & 428 & 15200 & 217 & 1 \\
80 & 285 & 109 & 17.2 & 458 & 16950 & 212 & \\
90 & 250 & 115 & 18.5 & 468 & 18400 & 204 & 3 \\
100 & 226 & 119 & 19.5 & 471 & 19600 & 196 & \\
110 & 207 & 122 & 20.4 & 471 & 20500 & 186 & \\
120 & 194 & 125 & 21.1 & 471 & 21300 & 177 & \\
130 & 184 & 127 & 21.7 & 471 & 22000 & 169 & \\
140 & 175 & 130 & 22.2 & 471 & 22600 & 161 & \\
150 & 167 & 132 & 22.7 & 471 & 23100 & 154 & \\
\hline
\end{tabular}


TABLE 1-(Continued)

\begin{tabular}{c|c|c|c|c|c|c|c}
\hline Age & $\begin{array}{c}\text { Number } \\
\text { of Trees } \\
\text { per Acre }\end{array}$ & $\begin{array}{c}\text { Average } \\
\text { Height } \\
\text { of Trees }\end{array}$ & $\begin{array}{c}\text { Average } \\
\text { Diameter } \\
\text { Breast High }\end{array}$ & $\begin{array}{c}\text { Basal } \\
\text { Area per } \\
\text { Acre }\end{array}$ & $\begin{array}{c}\text { Volume } \\
\text { per Acre }\end{array}$ & $\begin{array}{c}\text { Average } \\
\text { Annual } \\
\text { Growth }\end{array}$ & $\begin{array}{c}\text { Basis } \\
\text { Number } \\
\text { of Plots }\end{array}$ \\
\hline Years & Feet & Inches & Square Feet & Cubic Feet & Cubic Feet & \\
\hline
\end{tabular}

Site index 80 feet at 50 years

\begin{tabular}{r|r|r|r|r|r|r|r}
\hline 50 & 520 & 65 & 10.3 & 303 & 8100 & 162 & 5 \\
60 & 449 & 82 & 12.2 & 364 & 11400 & 190 & 5 \\
70 & 390 & 92 & 13.9 & 411 & 13700 & 196 & 7 \\
80 & 342 & 96 & 15.4 & 441 & 15200 & 190 & 3 \\
90 & 302 & 101 & 16.5 & 450 & 16600 & 184 & 3 \\
100 & 270 & 105 & 17.5 & 452 & 17600 & 176 & \\
110 & 248 & 107 & 18.3 & 452 & 18500 & 168 & \\
120 & 230 & 110 & 19.0 & 452 & 19200 & 160 & \\
130 & 218 & 112 & 19.5 & 452 & 19800 & 152 & 2 \\
140 & 208 & 114 & 19.9 & 452 & 20300 & 145 & \\
150 & 200 & 116 & 20.3 & 452 & 20800 & 139 & \\
\hline
\end{tabular}

Site index 70 feet at 50 years

\begin{tabular}{r|r|r|r|r|r|r|r}
\hline 50 & 630 & 57 & 9.2 & 288 & 6700 & 135 & 9 \\
60 & 539 & 71 & 10.9 & 346 & 9400 & 157 & 17 \\
70 & 468 & 80 & 12.4 & 390 & 11400 & 163 & 8 \\
80 & 410 & 84 & 13.7 & 418 & 12700 & 159 & 5 \\
90 & 362 & 88 & 14.7 & 427 & 13700 & 152 & 6 \\
100 & 325 & 91 & 15.6 & 430 & 14600 & 146 & 3 \\
110 & 297 & 93 & 16.3 & 430 & 15400 & 140 & 3 \\
120 & 275 & 95 & 16.9 & 430 & 15900 & 132 & 3 \\
130 & 260 & 97 & 17.4 & 430 & 16400 & 126 & 1 \\
140 & 249 & 99 & 17.8 & 430 & 16800 & 120 & 1 \\
150 & 241 & 101 & 18.1 & 430 & 17200 & 115 & \\
\hline
\end{tabular}

Site index 60 feet at 50 years

\begin{tabular}{r|r|r|r|r|r|r|r}
\hline 50 & 756 & 49 & 8.0 & 265 & 5300 & 106 & 5 \\
60 & 650 & 61 & 9.5 & 319 & 7400 & 123 & 10 \\
70 & 566 & 69 & 10.8 & 360 & 9000 & 128 & 10 \\
80 & 497 & 72 & 12.0 & 387 & 10000 & 125 & 1 \\
90 & 438 & 76 & 12.8 & 394 & 10800 & 120 & 1 \\
100 & 391 & 78 & 13.6 & 397 & 11500 & 115 & 6 \\
110 & 361 & 80 & 14.2 & 397 & 12000 & 109 & 4 \\
120 & 336 & 82 & 14.7 & 397 & 12500 & 104 & 2 \\
130 & 316 & 84 & 15.2 & 397 & 12950 & 100 & 1 \\
140 & 300 & 85 & 15.6 & 397 & 13300 & 95 & \\
150 & 290 & 87 & 15.8 & 397 & 13600 & 91 & 1 \\
\hline
\end{tabular}


TABLE 1-(Concluded)

\begin{tabular}{c|c|c|c|c|c|c|c}
\hline Age & $\begin{array}{c}\text { Number } \\
\text { of Trees } \\
\text { per Acre }\end{array}$ & $\begin{array}{c}\text { Average } \\
\text { Height } \\
\text { of Trees }\end{array}$ & $\begin{array}{c}\text { Average } \\
\text { Diameter } \\
\text { Breast High }\end{array}$ & $\begin{array}{c}\text { Basal } \\
\text { Area per } \\
\text { Acre }\end{array}$ & $\begin{array}{c}\text { Volume } \\
\text { per Acre }\end{array}$ & $\begin{array}{c}\text { Average } \\
\text { Annual } \\
\text { Growth }\end{array}$ & $\begin{array}{c}\text { Basis } \\
\text { Number } \\
\text { of Plots }\end{array}$ \\
\hline Years & Feet & Inches & Square Feet & Cubic Feet & Cuhrc Feet & \\
\hline
\end{tabular}

Sile index 50 feet at 50 years

\begin{tabular}{r|l|l|r|r|r|r|r}
\hline 50 & 930 & 41 & 6.8 & 237 & 3800 & 76 & 1 \\
60 & 795 & 51 & 8.1 & 284 & 5300 & 88 & 3 \\
70 & 690 & 58 & 9.2 & 320 & 6400 & 91 & 1 \\
80 & 604 & 61 & 10.2 & 343 & 7100 & 89 & 3 \\
90 & 531 & 63 & 11.0 & 350 & 7700 & 86 & \\
100 & 477 & 66 & 11.6 & 352 & 8200 & 82 & 1 \\
110 & 439 & 67 & 12.1 & 352 & 8600 & 78 & 3 \\
120 & 410 & 69 & 12.5 & 352 & 8900 & 74 & 2 \\
130 & 390 & 70 & 12.8 & 352 & 9200 & 71 & 2 \\
140 & 374 & 72 & 13.1 & 352 & 9400 & 67 & 1 \\
150 & 361 & 73 & 13.3 & 352 & 9650 & 64 & \\
\hline
\end{tabular}

Site index 40 feet at 50 years

\begin{tabular}{r|r|r|r|r|r|r|r}
\hline 50 & 1170 & 34 & 5.6 & 203 & 2700 & 54 & 1 \\
60 & 1000 & 42 & 6.7 & 244 & 3800 & 63 & 1 \\
70 & 869 & 47 & 7.6 & 276 & 4500 & 64 & 1 \\
80 & 760 & 49 & 8.4 & 296 & 5000 & 62 & \\
90 & 666 & 52 & 9.1 & 301 & 5500 & 61 & 1 \\
100 & 601 & 53 & 9.6 & 302 & 5800 & 58 & \\
110 & 550 & 55 & 10.0 & 302 & 6100 & 55 & \\
120 & 513 & 56 & 10.4 & 302 & 6350 & 53 & \\
130 & 483 & 57 & 10.7 & 302 & 6550 & 50 & \\
140 & 460 & 58 & 11.0 & 302 & 6700 & 48 & \\
150 & 441 & 59 & 11.2 & 302 & 6900 & 46 & \\
\hline
\end{tabular}

Site index 30 feet at 50 years

\begin{tabular}{r|r|r|r|l|l|l|l}
\hline 50 & 1590 & 26 & 4.4 & 166 & 2150 & 43 & \\
60 & 1366 & 32 & 5.2 & 201 & 3000 & 50 & \\
70 & 1180 & 36 & 5.9 & 227 & 3600 & 51 & 4 \\
80 & 1036 & 38 & 6.6 & 243 & 4000 & 50 & \\
90 & 907 & 40 & 7.1 & 248 & 4300 & 48 & \\
100 & 815 & 41 & 7.5 & 249 & 4600 & 46 & \\
110 & 750 & 42 & 7.8 & 249 & 4800 & 44 & \\
120 & 700 & 43 & 8.1 & 249 & 5000 & 42 & \\
130 & 662 & 44 & 8.3 & 249 & 5150 & 40 & 1 \\
140 & 629 & 45 & 8.5 & 249 & 5300 & 38 & \\
150 & 601 & 46 & 8.7 & 249 & 5425 & 36 & \\
\hline
\end{tabular}


TABLE 2

Normal Yield Table for White Fir, Including Trees 8 Inches and Over

\begin{tabular}{c|c|c|c|c|c|c|c|c}
\hline \hline Age & $\begin{array}{c}\text { Number } \\
\text { of Trees } \\
\text { per } \\
\text { Acre }\end{array}$ & $\begin{array}{c}\text { Average } \\
\text { Height } \\
\text { of Trees }\end{array}$ & $\begin{array}{c}\text { Average } \\
\text { Diameter } \\
\text { Breast } \\
\text { High }\end{array}$ & $\begin{array}{c}\text { Basal } \\
\text { Area } \\
\text { per } \\
\text { Acre }\end{array}$ & $\begin{array}{c}\text { Volume } \\
\text { per Acre }\end{array}$ & $\begin{array}{c}\text { Average } \\
\text { Annual } \\
\text { Growth }\end{array}$ & $\begin{array}{c}\text { Logs per } \\
\text { M. B. M. }\end{array}$ & $\begin{array}{c}\text { Basis } \\
\text { Number } \\
\text { of } \\
\text { Plots }\end{array}$ \\
\hline Years & & Feet & Inches & $\begin{array}{c}\text { Square } \\
\text { Feet }\end{array}$ & $\begin{array}{c}\text { Board } \\
\text { Feet }\end{array}$ & $\begin{array}{c}\text { Board } \\
\text { Feet }\end{array}$ & & \\
\hline
\end{tabular}

Site index 90 feet at 50 years

\begin{tabular}{r|r|r|r|r|r|r|r|r}
\hline 50 & 284 & 85 & 13.7 & 290 & 52400 & 1048 & 20 & 2 \\
60 & 275 & 100 & 15.6 & 363 & 81500 & 1358 & 16 & 3 \\
70 & 260 & 108 & 17.2 & 418 & 104400 & 1481 & 13 & 1 \\
80 & 238 & 114 & 18.6 & 451 & 122000 & 1525 & 11 & \\
90 & 216 & 119 & 19.8 & 463 & 136100 & 1513 & 10 & 3 \\
100 & 198 & 122 & 20.8 & 466 & 147800 & 1478 & 9 & \\
110 & 183 & 125 & 21.6 & 466 & 156000 & 1418 & 8 & \\
120 & 172 & 127 & 22.3 & 466 & 163800 & 1365 & 7 & \\
130 & 163 & 128 & 22.9 & 466 & 171000 & 1315 & 7 & \\
140 & 155 & 130 & 23.5 & 466 & 176700 & 1262 & 6 & \\
150 & 148 & 131 & 24.0 & 466 & 181300 & 1209 & 6 & \\
\hline
\end{tabular}

Site index 80 feet at 50 years

\begin{tabular}{r|r|r|r|r|r|r|r|r}
\hline 50 & 307 & 77 & 12.6 & 266 & 43200 & 864 & 22 & 5 \\
60 & 305 & 90 & 14.3 & 339 & 69000 & 1150 & 18 & 5 \\
70 & 290 & 97 & 15.8 & 395 & 89300 & 1275 & 15 & 7 \\
80 & 270 & 103 & 17.1 & 430 & 104100 & 1300 & 13 & 3 \\
90 & 249 & 107 & 18.1 & 442 & 117700 & 1308 & 11 & 3 \\
100 & 229 & 110 & 18.9 & 446 & 127400 & 1274 & 10 & \\
110 & 213 & 112 & 19.6 & 447 & 136100 & 1237 & 9 & \\
120 & 201 & 114 & 20.2 & 448 & 142600 & 1189 & 8 & \\
130 & 191 & 115 & 20.7 & 448 & 148500 & 1143 & 8 & 2 \\
140 & 183 & 117 & 21.2 & 448 & 153000 & 1093 & 8 & \\
150 & 177 & 118 & 21.6 & 448 & 157000 & 1047 & 7 & \\
\hline
\end{tabular}

Site index 70 feet at 50 years

\begin{tabular}{r|r|r|r|r|r|r|r|r}
\hline 50 & 328 & 68 & 11.5 & 236 & 31900 & 638 & 26 & 9 \\
60 & 334 & 80 & 13.1 & 310 & 52600 & 877 & 21 & 17 \\
70 & 321 & 87 & 14.4 & 365 & 69600 & 994 & 18 & 8 \\
80 & 301 & 92 & 15.6 & 399 & 82200 & 1027 & 15 & 5 \\
90 & 279 & 95 & 16.5 & 414 & 91800 & 1020 & 13 & 6 \\
100 & 260 & 98 & 17.2 & 419 & 100700 & 1007 & 12 & 3 \\
110 & 243 & 100 & 17.8 & 422 & 108000 & 982 & 11 & 3 \\
120 & 230 & 102 & 18.3 & 423 & 113100 & 942 & 10 & 3 \\
130 & 220 & 103 & 18.8 & 424 & 118100 & 908 & 10 & 1 \\
140 & 212 & 104 & 19.1 & 424 & 121800 & 870 & 9 & 1 \\
150 & 207 & 105 & 19.4 & 425 & 125400 & 836 & 9 & \\
\hline
\end{tabular}


TABLE 2-(Concluded)

\begin{tabular}{c|c|c|c|c|c|c|c|c}
\hline \hline Age & $\begin{array}{c}\text { Number } \\
\text { of Trees } \\
\text { per } \\
\text { Acre }\end{array}$ & $\begin{array}{c}\text { Average } \\
\text { Height } \\
\text { of Trees }\end{array}$ & $\begin{array}{c}\text { Average } \\
\text { Diameter } \\
\text { Breast } \\
\text { High }\end{array}$ & $\begin{array}{c}\text { Basal } \\
\text { Area } \\
\text { per } \\
\text { Acre }\end{array}$ & $\begin{array}{c}\text { Volume } \\
\text { per Acre }\end{array}$ & $\begin{array}{c}\text { Average } \\
\text { Annual } \\
\text { Growth } \\
\text { per Acre }\end{array}$ & $\begin{array}{c}\text { Logs per } \\
\text { M. B. M. M. }\end{array}$ & $\begin{array}{c}\text { Number } \\
\text { of } \\
\text { Plots }\end{array}$ \\
\hline Years & & Feet & Inches & $\begin{array}{c}\text { Square } \\
\text { Feet }\end{array}$ & $\begin{array}{c}\text { Board } \\
\text { Feet }\end{array}$ & $\begin{array}{c}\text { Board } \\
\text { Feet }\end{array}$ & & \\
\hline
\end{tabular}

Site index 60 feet at 50 years

\begin{tabular}{r|r|r|r|r|r|r|r|r}
\hline 50 & 317 & 60 & 10.4 & 187 & 20600 & 412 & 30 & 5 \\
60 & 351 & 70 & 11.8 & 268 & 36500 & 608 & 26 & 10 \\
70 & 348 & 76 & 13.0 & 322 & 50000 & 714 & 22 & 10 \\
80 & 331 & 80 & 14.1 & 359 & 60000 & 750 & 19 & 1 \\
90 & 306 & 83 & 14.9 & 372 & 67500 & 750 & 17 & 1 \\
100 & 287 & 86 & 15.6 & 379 & 74000 & 740 & 15 & 6 \\
110 & 272 & 88 & 16.1 & 383 & 79200 & 720 & 14 & 4 \\
120 & 259 & 89 & 16.5 & 385 & 83600 & 696 & 13 & 2 \\
130 & 248 & 90 & 16.9 & 387 & 88100 & 678 & 12 & 1 \\
140 & 240 & 91 & 17.2 & 388 & 91400 & 633 & 11 & \\
150 & 233 & 92 & 17.5 & 389 & 93800 & 625 & 11 & 1 \\
\hline
\end{tabular}

Site index 50 feet at 50 years

\begin{tabular}{r|r|r|r|r|r|r|r|r}
\hline 50 & 260 & 51 & 9.1 & 118 & 9700 & 194 & 35 & 1 \\
60 & 341 & 60 & 10.5 & 206 & 21100 & 352 & 32 & 3 \\
70 & 360 & 65 & 11.6 & 263 & 30500 & 436 & 28 & 1 \\
80 & 352 & 69 & 12.5 & 299 & 37600 & 470 & 25 & 3 \\
90 & 332 & 71 & 13.2 & 315 & 43300 & 481 & 22 & \\
100 & 311 & 74 & 13.8 & 323 & 48400 & 484 & 20 & 1 \\
110 & 295 & 75 & 14.3 & 327 & 51900 & 472 & 18 & 3 \\
120 & 283 & 76 & 14.6 & 330 & 54800 & 457 & 17 & 2 \\
130 & 274 & 77 & 14.9 & 332 & 57800 & 445 & 16 & 2 \\
140 & 267 & 78 & 15.2 & 334 & 59700 & 426 & 15 & 1 \\
150 & 260 & 79 & 15.4 & 336 & 61600 & 411 & 15 & \\
\hline
\end{tabular}

Site index 40 feet at 50 years

\begin{tabular}{r|r|r|r|r|r|r|r|r}
\hline 50 & 123 & 43 & 7.9 & 42 & 2200 & 44 & 40 & 1 \\
60 & 265 & 50 & 9.0 & 117 & 9200 & 153 & 37 & 1 \\
70 & 330 & 54 & 10.0 & 178 & 15700 & 224 & 34 & 1 \\
80 & 347 & 58 & 10.9 & 223 & 21100 & 264 & 31 & \\
90 & 342 & 60 & 11.5 & 246 & 25800 & 287 & 28 & 1 \\
100 & 329 & 62 & 11.9 & 255 & 29000 & 290 & 26 & \\
110 & 315 & 63 & 12.3 & 261 & 31700 & 288 & 24 & \\
120 & 303 & 64 & 12.7 & 265 & 33900 & 283 & 22 & \\
130 & 294 & 65 & 12.9 & 269 & 36000 & 277 & 21 & \\
140 & 287 & 65 & 13.2 & 272 & 37500 & 268 & 20 & \\
150 & 280 & 66 & 13.4 & 274 & 38800 & 259 & 19 & \\
\hline
\end{tabular}


Volume board measure of plots in per cent of yield table.

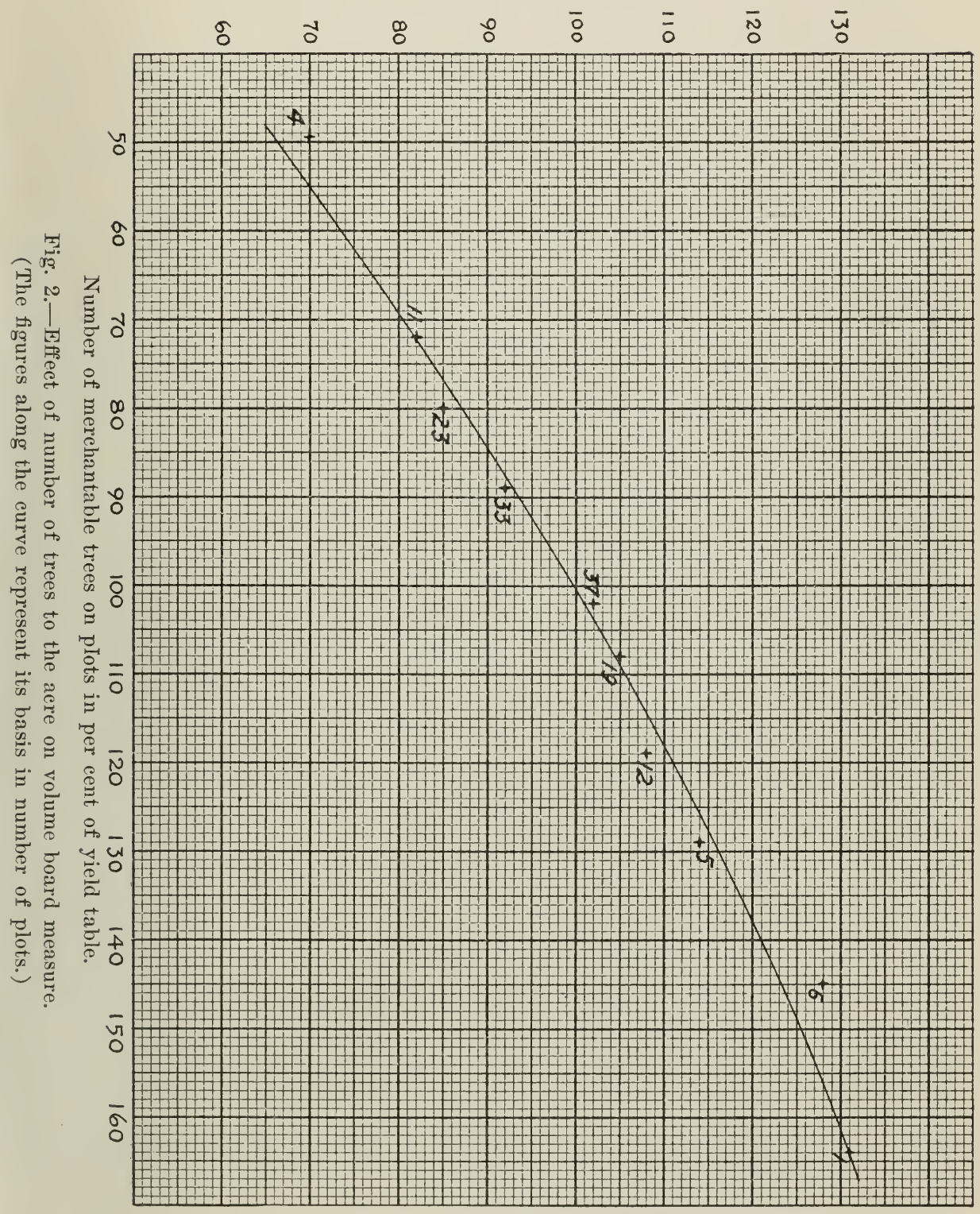




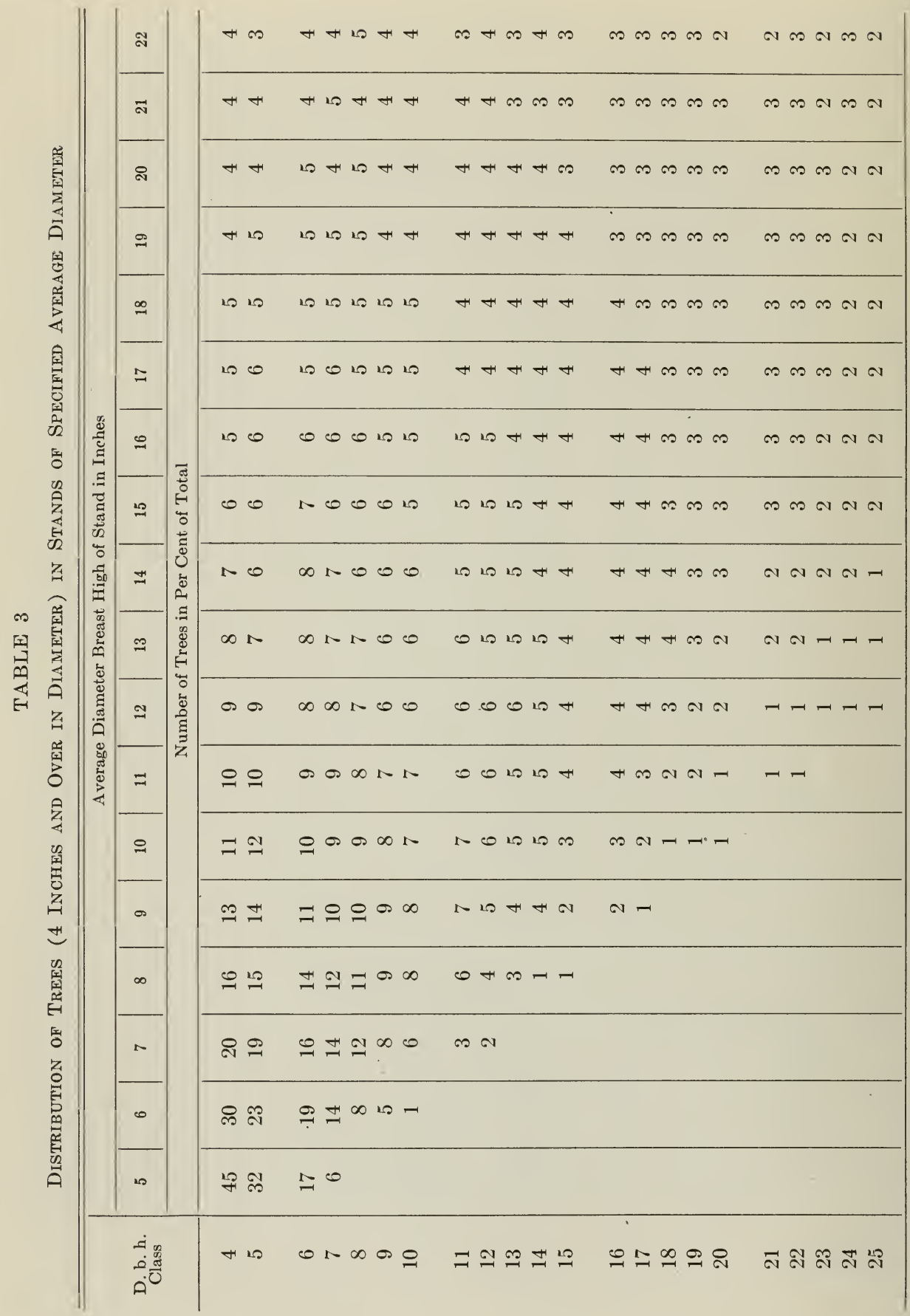




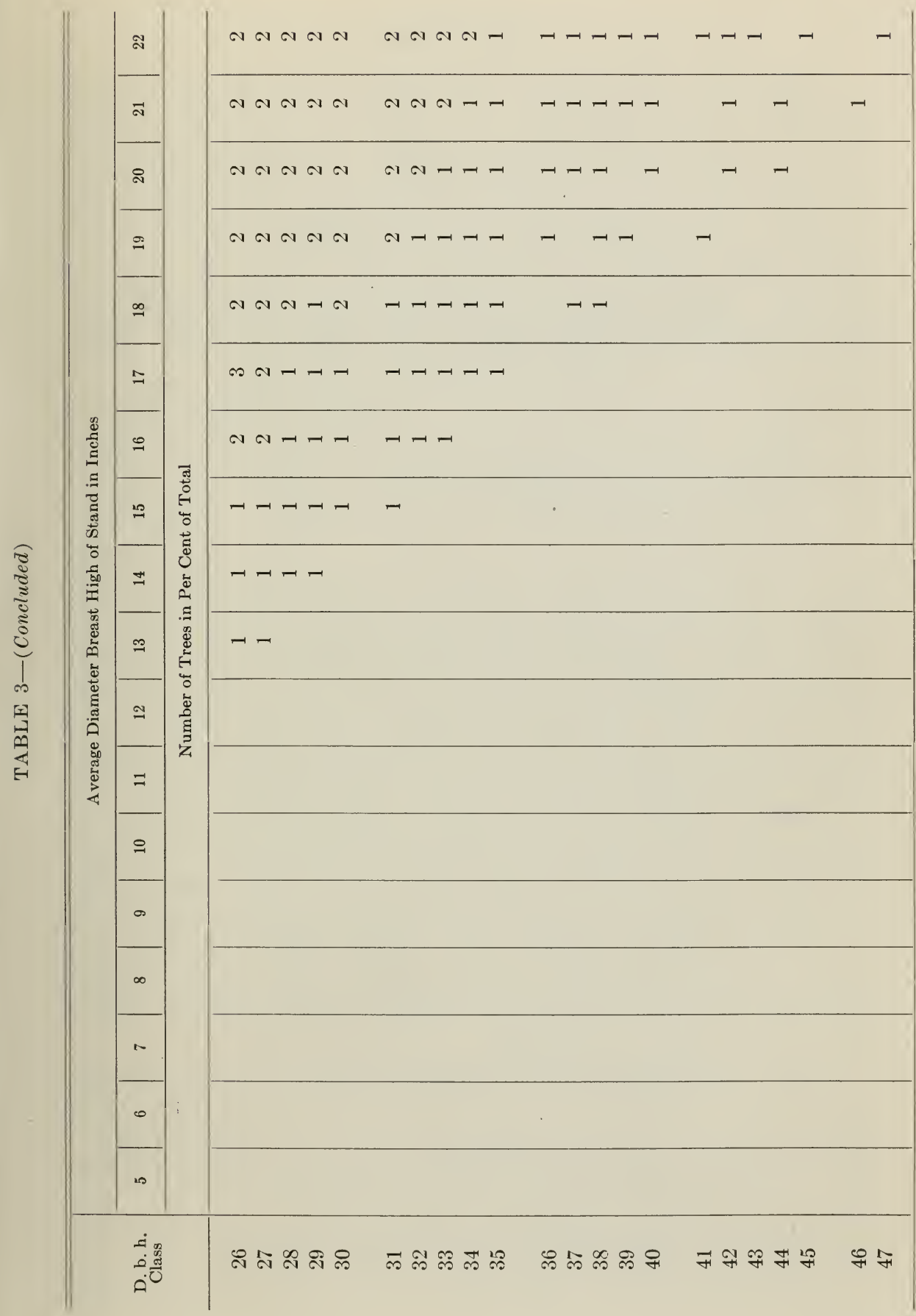




\section{DISCUSSION}

One of the most important observations on the growth of white fir stands is its exceptionally slow growth up to an age of about 30 years, as shown graphically for height of dominants in figure 1, and the marked acceleration from that age up to about the 90th year, so sudden and persistent that its growth during this 60-year period compares favorably with the growth of redwood (Sequoia sempervirens Endl.) stands of the northern coast counties in their first 60 years. Bruce $^{5}$ reports that redwood probably grows faster than any other conifer and can be raised on the shortest rotation. Values from equivalent sites of the two species are compared:

\begin{tabular}{|c|c|c|}
\hline Redw & od (after Bruce) & White Fir ${ }^{6}$ \\
\hline Site & III & $70-\mathrm{ft}$. \\
\hline Age & 60 & 90 \\
\hline Average diameter breast high, in & 14.9 & 14.7 \\
\hline Volume board measure to the ac & 93,000 & 91,800 \\
\hline
\end{tabular}

Perhaps advantage can be taken of the peculiar growth of white fir, so as to reduce its 90 -year growth, practically all of which occurs between the 30 th and 90 th years, to a 60 -year rotation. This plan seems feasible on areas where the species is found pure, provided the qualities of its wood can be shown to be such that it will rank with the woods of other second-growth species of the pine region. It is perhaps the most prolific seeder of the main timber belt of the region. It is considered quite tolerant of shade. These qualities adapt it to the shelterwood system of silviculture, wherein the establishment of reproduction is provided for before all of the overwood is removed. The dominant trees of this lower story should average about 16 feet in height when they are approximately 30 years old, as indicated by measurements taken beneath older timber. They will then have passed through the period of slow growth, and if given available light and space by the removal of overwood, should make the remarkable growth shown in the tables.

Even though such intensive management may not yet be practical, the slow growth of white fir in its seedling and sapling stages brings out forcibly the value of advance reproduction. Thirty years or more are lost on lands where fire destroys this young growth, or where it is heedlessly killed by present logging methods.

5 Bruce, D., Preliminary yield tables for second-growth redwood. University of California Agr. Exp. Sta. Bul. 361, pp. 427-467, figs. 1-5. 1923.

6 Measurements taken on young individual trees indicate that at 30 years, dominant white firs are about 16 feet high and about 2 inches in diameter breast high. 


\section{APPENDIX}

\section{DISTRIBUTION OF BASIC DATA}

Measurements of 179 sample plots were available for the study, 128 of which were gathered by the staff of the Division of Forestry, University of California, and 51 by the Branch of Research of the California District, United States Forest Service.

In geographical range, these plots represent samples from practically every Sierra county between Modoc and Fresno. Distribution by watershed tributary to the Sacramento and San Joaquin Rivers, together with a number from the east side of the Sierra, is shown in table 4 .

\section{TABLE 4}

Geographical Distribution of Plots

\begin{tabular}{|c|c|}
\hline Watershed & $\begin{array}{c}\text { Number o } \\
\text { Plots }\end{array}$ \\
\hline Pitt River.. & 4 \\
\hline Chico Creek. & 1 \\
\hline Butte Creek. & 18 \\
\hline Feather River.. & 41 \\
\hline Yuba River......... & 6 \\
\hline Bear River.................. & 3 \\
\hline American River & .. 21 \\
\hline Stanislaus River.. & 10 \\
\hline Tuolumne River.. & 43 \\
\hline Fresno River....... & 4 \\
\hline West Side of Sierra..... & 151 \\
\hline East Side of Sierra.... & .. 28 \\
\hline
\end{tabular}

Effort was made to gather plots homogeneous in species, stocking, age, and site-a combination which is not maintained in any considerable area of natural stands-thus setting conditions that necessarily limit plot size. Table 5 shows distribution of plots by area classes : 
TABLE 5

Distribution of Plots by Area Classes

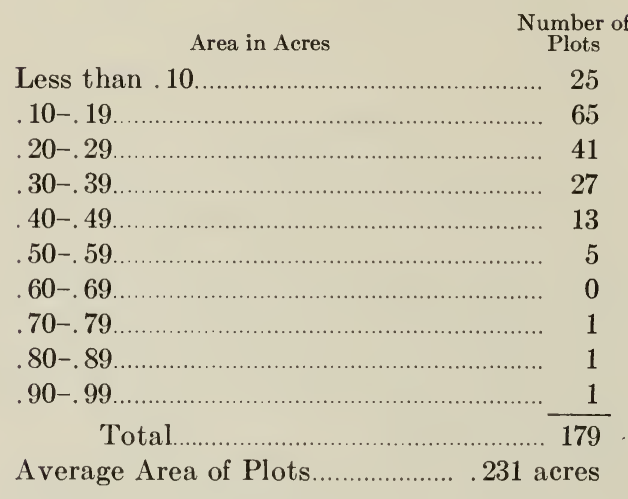

It was found that the basal area to the acre of these plots is independent of plot area, which means that due care was exercised in laying out boundaries, and that plot areas represent the actual areas used by the enclosed stands.

Of the total number, 9 plots were discarded because they were over 150 years of age, ranging from 155 to 180, as they seemed insufficient in number for their range to put reliance in their averages. One plot, a 30-year-old one, in which all trees down to .1 inch diameter were measured, was discarded because it contained no trees as large as 4 inches in diameter breast high. The site classification of figure 1 was then based on the 169 plots thus far accepted. Information on distribution of these by site and age classes is given in table 6 .

TABLE 6

Distribution of Plots by Site and Age Classes

\begin{tabular}{|c|c|c|c|c|c|c|c|c|}
\hline \multirow{2}{*}{ Age } & \multicolumn{8}{|c|}{ Site-Height in Feet of Average Dominant White Fir at 50 Years } \\
\hline & $25-34$ & $35-44$ & $45-54$ & $55-64$ & $65-74$ & 75-84 & $85-94$ & Total \\
\hline $40-49$. & & \multirow[t]{2}{*}{1} & & 5 & \multirow{2}{*}{$\begin{array}{r}5 \\
15\end{array}$} & & \multirow{2}{*}{$\begin{array}{l}2 \\
2\end{array}$} & \multirow{2}{*}{$\begin{array}{l}13 \\
31\end{array}$} \\
\hline $50-59$. & & & 2 & 4 & & 8 & & \\
\hline $60-69$. & & \multirow{4}{*}{$\begin{array}{l}2 \\
1 \\
1\end{array}$} & 4 & 16 & 14 & 9 & \multirow[t]{3}{*}{2} & 47 \\
\hline $70-79$ & \multirow[t]{2}{*}{4} & & \multirow[t]{2}{*}{3} & 1 & \multirow{2}{*}{$\begin{array}{l}7 \\
3\end{array}$} & \multirow{2}{*}{$\begin{array}{l}5 \\
1\end{array}$} & & \multirow{2}{*}{$\begin{array}{r}21 \\
7\end{array}$} \\
\hline $80-89$. & & & & 2 & & & & \\
\hline $90-99$. & & & 1 & 5 & 6 & \multirow[t]{2}{*}{2} & \multirow[t]{2}{*}{3} & 17 \\
\hline $100-109$ & & & 1 & 5 & 2 & & & 8 \\
\hline $110-119$. & & & 4 & 3 & 4 & & & 11 \\
\hline $120-129$. & \multirow[t]{2}{*}{1} & & 1 & 2 & 2 & & & 6 \\
\hline $130-139$. & & & 2 & & \multirow{2}{*}{2} & \multirow[t]{2}{*}{2} & & \multirow{2}{*}{$\begin{array}{l}0 \\
6 \\
2\end{array}$} \\
\hline $140-149$. & & & 1 & 1 & & & & \\
\hline Total...... & 5 & 5 & 19 & 44 & 60 & 27 & 9 & 169 \\
\hline
\end{tabular}


Table 7 shows the average composition of the 169 plots in basal area by species.

\section{TABLE 7}

Composition of Piots

\begin{tabular}{|c|c|}
\hline White Fir. Sp............ & $\begin{array}{l}\text { Per Cent of Basal Area } \\
\ldots \ldots \ldots . . \quad 82.0\end{array}$ \\
\hline Sugar Pine.... & $\begin{array}{ll}\ldots . . & 4.9\end{array}$ \\
\hline Douglas Fir................. & 4.5 \\
\hline Western Yellow Pine. & 3.2 \\
\hline 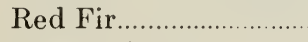 & 2.8 \\
\hline Incense Cedar. & 2.2 \\
\hline Miscellaneous... & .4 \\
\hline & 100.0 \\
\hline
\end{tabular}

Investigation indicates that basal area to the acre is independent of composition, or at least that there is not enough of any species other than white fir to affect basal area. No appreciable error should result, then, from using white fir volume tables for all species, even though the bark of white fir is thinner than the bark of incense cedar and the pines.

\section{REJECTION OF ABNORMAL PLOTS}

In the field, plots whose crown canopies were as complete as seemed consistent with age, were considered normal and suitable as a basis for the yield tables. But the personal factor might have played such a large part in defining normality of stocking for field purposes, that a further check was necessary.

Preliminary curves of basal area growth were fitted and harmonized by site classes. Then the deviations of the basal area of each plot from the basal area curve, fitted to nearest foot of site and nearest year of age, were computed and grouped, and are shown in table 8 .

TABLE 8

Deviation of Plot Basal Arfa from Basal Area Curve

Per Cent Deviation

Number of Plots

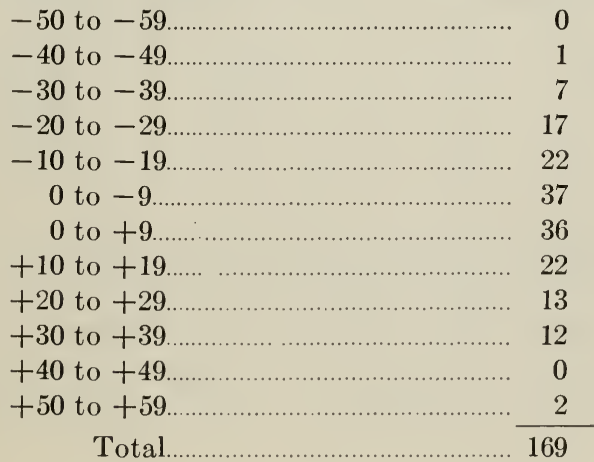


The probable error was computed to be \pm 12.6 per cent; that is, the basal areas of half the plots deviate from the curved basal area for site and age by less than 12.6 per cent, and half by more. Three times the probable error (in this case about 38 per cent) is commonly used as the limit of error, so that plots whose deviations exceeded \pm 36 per cent were scrutinized, and accepted or rejected by other facts gathered from composition, plot description, etc. Twelve plots were rejected for the following reasons:

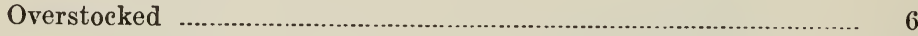

Understocked ................................................................................. 2

Too high percentage of cedar ......................................................... 2

Too high percentage of Douglas fir .......................................... 1

Too high percentage of sugar pine .............................................. 1

The remaining 157 plots were used as the basis of the yield tables.

\section{RELATION BETWEEN HEIGHTS OF THE VARIOUS SPECIES IN MIXTURE}

This relationship was studied between the dominant trees of white fir and other species, on those plots where there was a sufficient number of another species for its height-diameter curve. Heights of the average dominants of associated species in percentage of average dominant white fir together with their coefficients of correlation are shown in table 9 .

\section{TABLE 9}

Relation Between the Heights of Average Dominants of White Fir and Assoclated SPECIES

\begin{tabular}{|c|c|c|c|}
\hline Species & $\begin{array}{c}\text { Per Cent of } \\
\text { White Fir Height }\end{array}$ & $\begin{array}{l}\text { Coefficient of } \\
\text { Correlation }\end{array}$ & $\begin{array}{c}\text { Basis Number } \\
\text { of Plots }\end{array}$ \\
\hline Sugar pine.. & 92 & $.94 \pm .01$ & 30 \\
\hline Western yellow pine... & 100 & $.92 \pm .05$ & 14 \\
\hline Red fir................................... & 99 & $.88 \pm .05$ & 11 \\
\hline Douglas fir................ & 94 & $.48 \pm .16$ & 10 \\
\hline
\end{tabular}

There is very good correlation between white fir on the one hand, and sugar pine, western yellow pine and red fir on the other. With Douglas fir, however, the value of the coefficient is nullified by its high probable error, so that it is assumed that for this species the samples on which the correlation is based was not adequate. 
Since western yellow pine and red fir make practically the same height growth as white fir on the same sites and within the age limits of the data (45 years to 150 years), one site classification, based on height of average dominant should serve for these three species. Another classification will be needed for sugar pine and perhaps for Douglas fir.

\section{BASIS OF THE STAND TABLE}

Progressive steps in the construction of table 3 were as follows:

(1) Plots were sorted by 10 -foot site classes and 10-year age classes, and distribution of trees to the acre by diameter classes for each site-age class was computed in cumulative per cent. Table 10 shows an example of the computation for a random site-age class.

\section{TABLE 10}

Distribution of Number of Trees to the ACre for Site 80-FT., 50-Year Age Class

(Average diameter breast high 11.2 inches. Basis 5 plots.)

\begin{tabular}{|c|c|c|c|}
\hline D. b. h. inches & $\begin{array}{l}\text { Average number of } \\
\text { trees to the acre }\end{array}$ & $\begin{array}{l}\text { Per cent of total } \\
\text { number }\end{array}$ & Cumulative per cent \\
\hline 4 & 34 & 7 & 7 \\
\hline 5 & 58 & 12 & 19 \\
\hline 6 & 42 & 8 & 27 \\
\hline 7 & 51 & 10 & 37 \\
\hline 8 & 38 & 8 & 45 \\
\hline 9 & 38 & 8 & 53 \\
\hline 10 & 38 & 8 & 61 \\
\hline 11 & 36 & 7 & 68 \\
\hline 12 & 12 & 2 & 70 \\
\hline 13 & 24 & 5 & 75 \\
\hline 14 & 22 & 4 & 79 \\
\hline 15 & 23 & 5 & 84 \\
\hline 16 & 18 & 4 & 88 \\
\hline 17 & 19 & 4 & 92 \\
\hline 18 & 9 & 1.8 & 93.8 \\
\hline 19 & 12 & 2 & 95.8 \\
\hline 20 & 3 & 0.6 & 96.4 \\
\hline 21 & 9 & 1.8 & 98.2 \\
\hline 22 & 4 & 0.8 & 99.0 \\
\hline 23 & 1 & 0.2 & 99.2 \\
\hline 24 & 3 & 0.6 & 99.8 \\
\hline 25 & 1 & 0.2 & 100 \\
\hline Total... & 495 & 100 & \\
\hline
\end{tabular}


(2) Values of each site-age class were plotted on ordinary crosssection paper, cumulative per cents over their corresponding diameters breast high, and the points connected by straight lines. (They were first plotted on arithmetic probability paper, as proposed by Bruce, ${ }^{7}$ but as the distribution was obviously not normal, and the use of the paper actually distorted interpolated values in the lower diameter classes, the method was abandoned). The striking similarity in form of the curves regardless of site or age, as shown by close checks between deciles for stands which had the same average diameter though differing widely in site and age, indicated that the distribution was a function primarily of average diameter.

(3) These curves were then grouped by average diameter breast high; and for each 1-inch class, deciles and the 98th percentile were averaged and plotted as shown in figure 3 .

(4) Deciles and the 98th percentile were harmonized and table 3 constructed.

As a check, the coefficient of correlation between average diameter breast-high and the 50th and 90 th percentiles were computed and found to be as follows:

Average diameter breast high and 50 th percentile, $.83 \pm .02$.

Average diameter breast high and 90 th percentile, $.99 \pm .01$.

\section{VOLUME TABLES FOR WHITE FIR}

Tables 11, 12, and 13, volume tables for white fir, were constructed as a preliminary step in the yield study. They are based on taper measurements of over 600 trees, taken by the United States Forest Service in Siskiyou County in 1905.

7 Bruce, D., A method of preparing timber-yield tables. Jour. Agr. Research, 32: 543-557, figs. 1-8. 1926. 


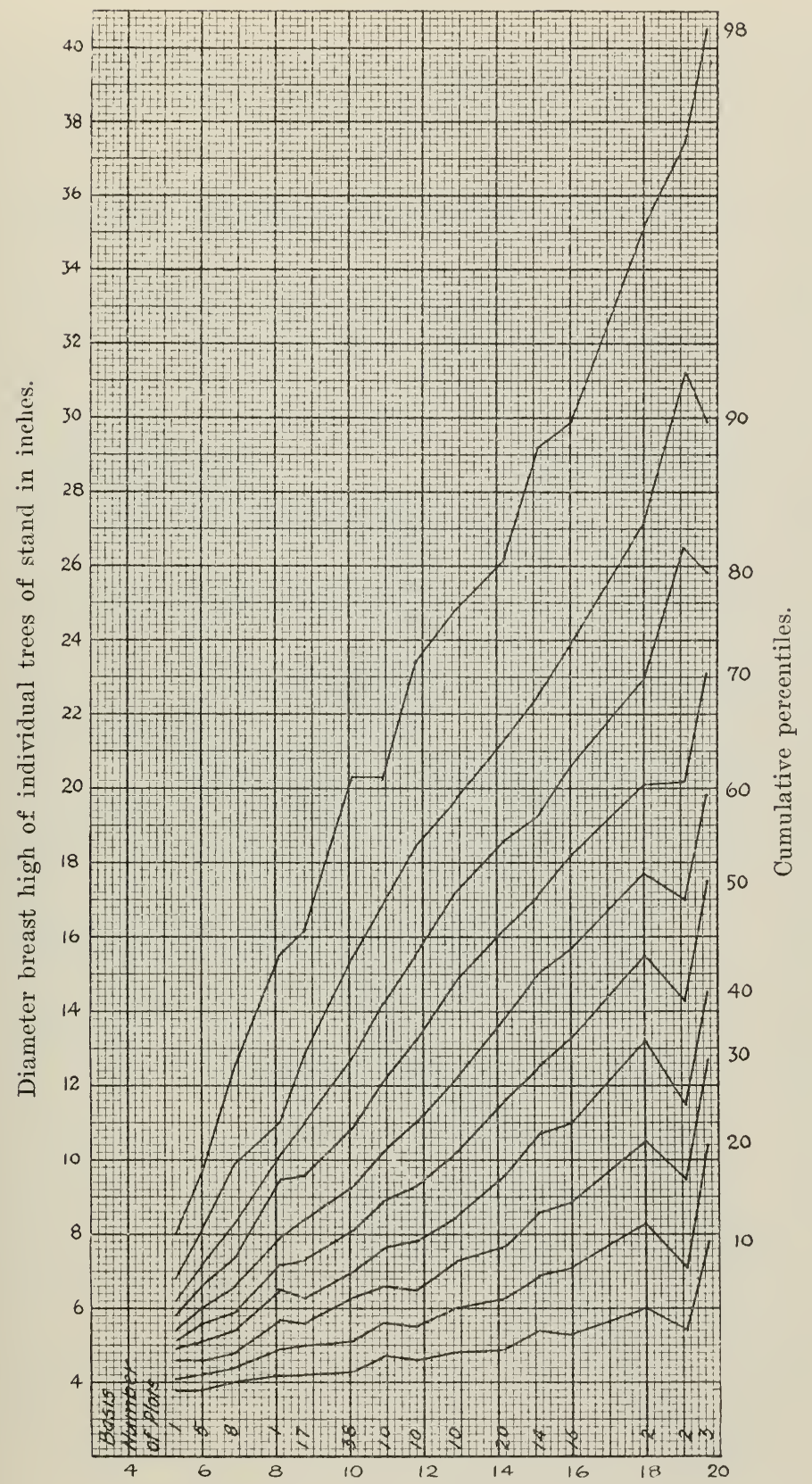

Average diameter breast high of stand in inches.

Fig. 3.-Distribution of diameter elasses in stands of specified average diameter breast high. 


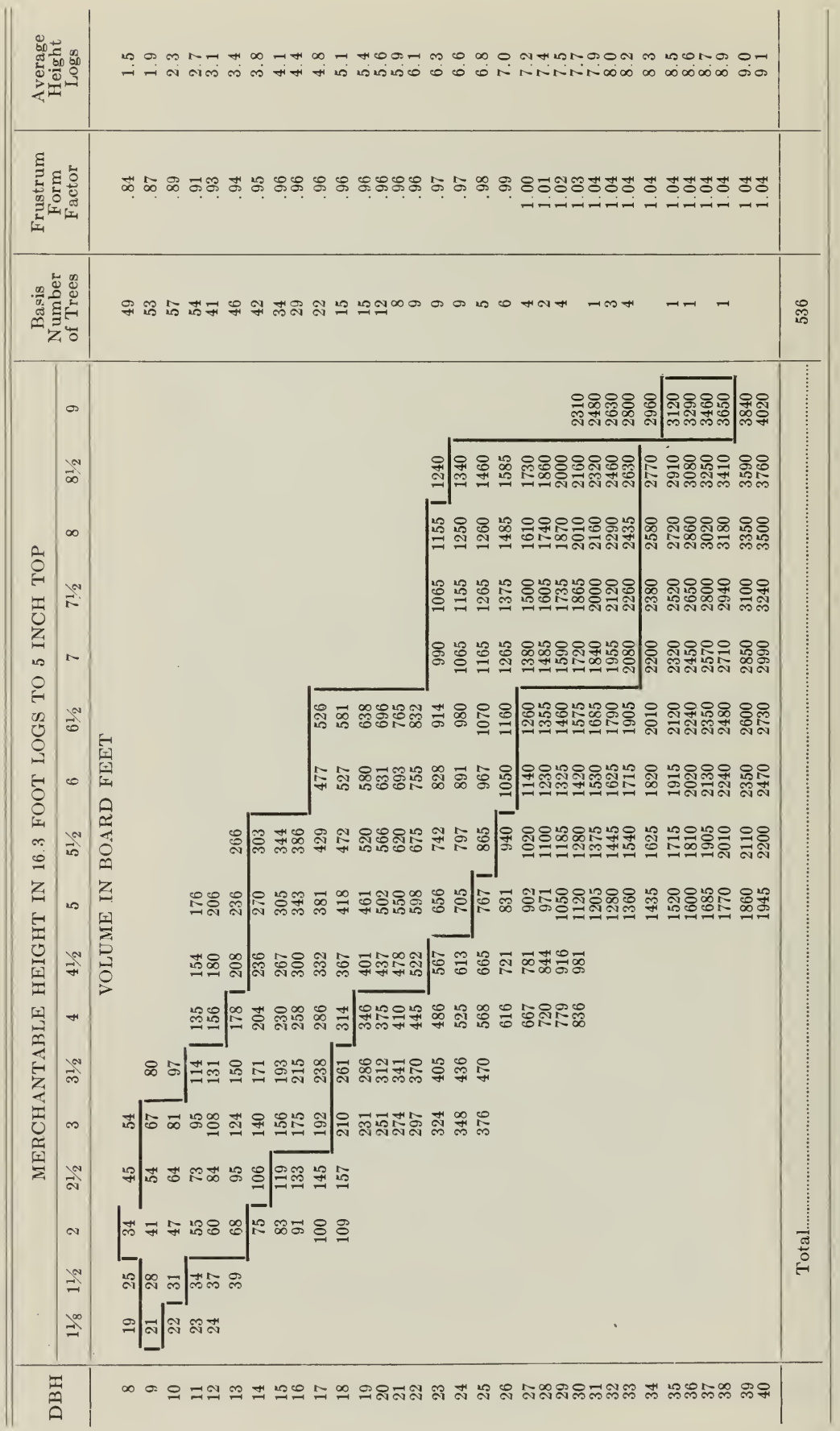




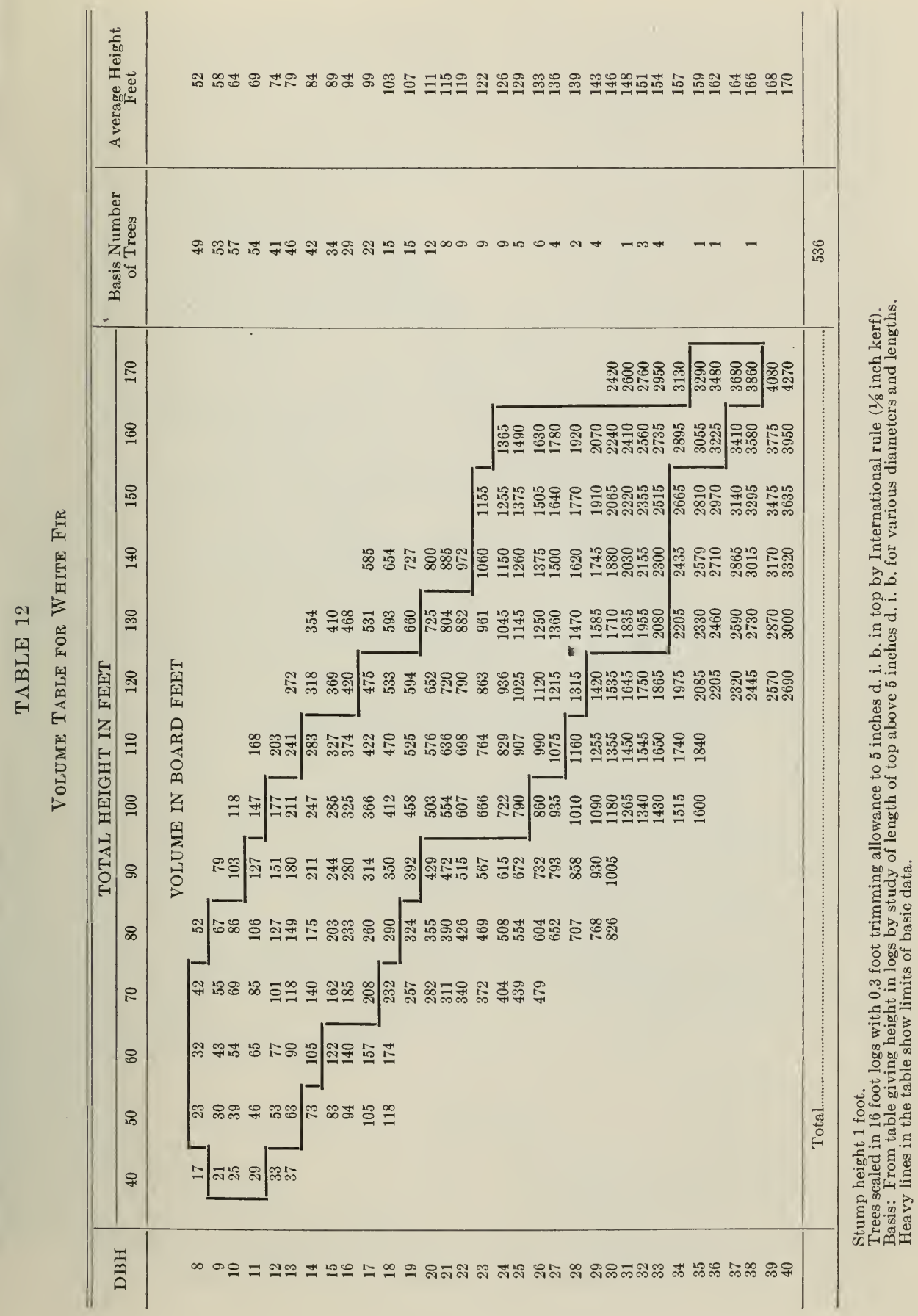




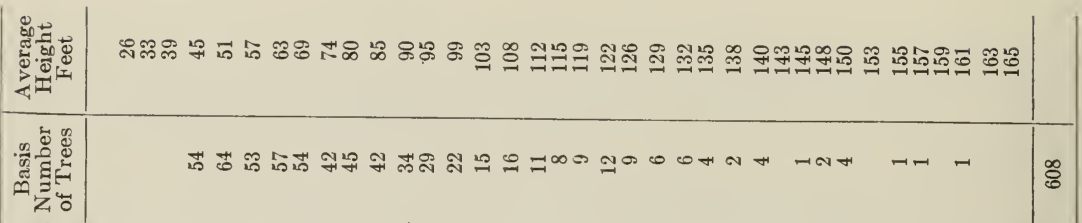

오

$\stackrel{\odot}{Ð}$

ํ.

워

$\stackrel{9}{9}$

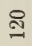

要


으

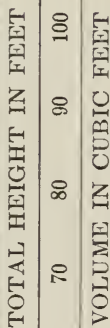

8

in

2

우

ณ

ఇా

เล

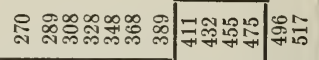

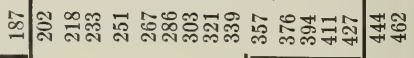

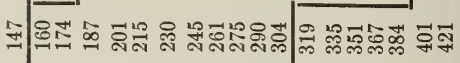

ก $\infty$

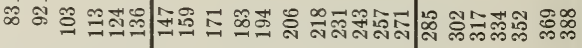

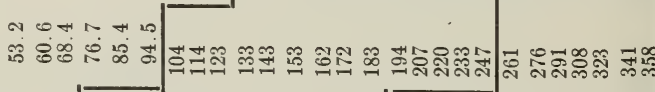
- 0 0.

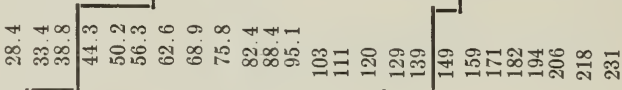

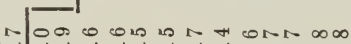

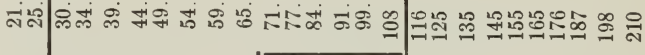

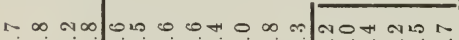

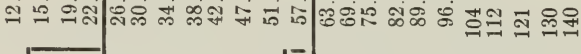

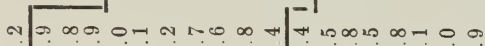

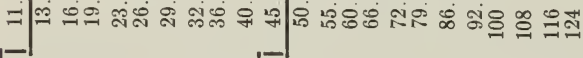

ชู่

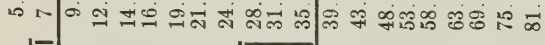

कळ

๓ 0 क

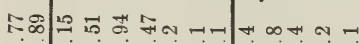

rim is 0 -

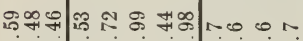

-

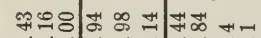

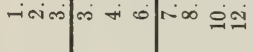

सุ⿺辶⿻

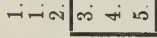

ำㅇำ응

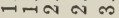

ณะ⿻

ori- 


\section{BULLETINS}

No.

253. Irrigation and Soil Conditions in the Sierra Nevada Foothills, California.

261. Melaxuma of the Walnut, "Juglans regia."

262. Citrus Diseases of Florida and Cuba Compared with Those of California.

263. Size Grades for Ripe Olives.

268. Growing and Grafting Olive Seedlings.

273. Preliminary Report on Kearney Vine. yard Experimental Drain.

275. The Cultivation of Belladonna in California.

276. The Pomegranate.

277. Sudan Grass.

278. Grain Sorghums.

279. Irrigation of Rice in California.

283. The Olive Insects of California.

294. Bean Culture in California.

304. A Study of the Effects of Freezes on Citrus in California.

310. Plum Pollination.

312. Mariout Barley.

313. Pruning Young Deciduous Fruit Trees.

319. Caprifigs and Caprification.

324. Storage of Perishable Fruit at Freezing Temperatures.

325. Rice Irrigation Measurements and Experiments in Sacramento Valley, 1914-1919.

328. Prune Growing in California.

331. Phylloxera-Resistant Stocks.

335. Cocoanut Meal as a Feed for Dairy Cows and Other Livestock.

339. The Relative Cost of Making Logs from Small and Large Timber.

340. Control of the Pocket Gopher in California.

343. Cheese Pests and Their Control.

344. Cold Storage as an Aid to the Marketing of Plums.

346. Almond Pollination.

347. The Control of Red Spiders in Deciduous Orchards.

348. Pruning Young Olive Trees.

349. A Study of Sidedraft and Tractor Hitches.

350. Agriculture in Cut-over Redwood Lands.

352. Further Experiments in Plum Pollination.

353. Bovine Infectious Abortion.

354. Results of Rice Experiments in 1922.

357. A Self-mixing Dusting Machine for Applying Dry Insecticides and Fungicides.

358. Black Measles, Water Berries, and Related Vine Troubles.

361. Preliminary Yield Tables for Second Growth Redwood.

362. Dust and the Tractor Engine.

363. The Pruning of Citrus Trees in California.

364. Fungicidal Dusts for the Control of Bunt.

365. Avocado Culture in California.
No.

366. Turkish Tobacco Culture, Curing and Marketing.

367. Methods of Harvesting and Irrigation in Relation of Mouldy Walnuts.

368. Bacterial Decomposition of Olives during Pickling.

369. Comparison of Woods for Butter Boxes.

370. Browning of Yellow Newtown Apples. 371. The Relative Cost of Yarding Small and Large Timber.

372. The Cost of Producing Market Milk and Butterfat on 246 California Dairies.

373. Pear Pollination.

374. A Survey of Orchard Practices in the Citrus Industry of Southern California.

375. Results of Rice Experiments at Cortena, 1923.

376. Sun-Drying and Dehydration of Walnuts.

377. The Cold Storage of Pears.

379. Walnut Culture in California.

380. Growth of Eucalyptus in California Plantations.

381. Growing and Handling Asparagus Crowns.

382. Pumping for Drainage in the San Joaquin Valley, California.

383. Monilia Blossom Blight (Brown Rot) of Apricot.

385. Pollination of the Sweet Cherry.

386. Pruning Bearing Deciduous Fruit Trees.

387. Fig Smut.

388. The Principles and Practice of Sun. drying Fruit.

389. Berseem or Egyptian Clover.

390. Harvesting and Packing Grapes in California.

391. Machines for Coating Seed Wheat with Copper Carbonate Dust.

392. Fruit Juice Concentrates.

393. Crop Sequences at Davis.

394. Cereal Hay Production in California. Feeding Trials with Cereal Hay.

595. Bark Diseases of Citrus Trees.

396. The Mat Bean (Phaseolus aconilifo. lius).

397. Manufacture of Roquefort Type Cheese from Goat's Milk.

398. Orchard Heating in California.

399. The Blackberry Mite, the Cause of Redberry Disease of the Himalaya Blackberry, and its Control.

400. The Utilization of Surplus Plums.

401. Cost of Work Horses on California Farms.

402. The Codling Moth in Walnuts.

403. Farm-Accounting Associations.

404. The Dehydration of Prunes.

405. Citrus Culture in Central California.

406. Stationary Spray Plants in California.
No.

87. Alfalfa.

117. The Selection and Cost of a Small Pumping Plant.

127. House Fumigation.

129. The Control of Citrus Insects.

136. Melilotus indica as a Green-Manure Crop for California.

144. Oidium or Powdery Mildew of the Vine.
CIRCULARS

No.

157. Control of the Pear Scab.

160. Lettuce Growing in California.

164. Small Fruit Culture in California.

166. The County Farm Bureau.

170. Fertilizing California Soils for the 1918 Crop.

173. The Construction of the Wood-Hoop Silo.

178. The Packing of Apples in California. 
No.

179. Factors of Importance in Producing Milk of Low Bacterial Count.

190. Agriculture Clubs in California.

199. Onion Growing in California.

202. County Organizations for Rural Fire Control.

203. Peat as a Manure Substitute.

209. The Function of the Farm Bureau.

210. Suggestions to the Settler in California.

212. Salvaging Rain-Damaged Prunes.

215. Feeding Dairy Cows in California.

217. Methods for Marketing Vegetables in California.

220. Unfermented Fruit Juices.

228. Vineyard Irrigation in Arid Climates.

230. Testing Milk, Cream, and Skim Milk for Butterfat.

231. The Home Vineyard.

232. Harvesting and Handling California Cherries for Eastern Shipment.

234. Winter Injury to Young Walnut Trees during 1921-22.

235. Soil Analysis and Soil and Plant Inter-relations.

236. The Common Hawks and Owls of California from the Standpoint of the Rancher.

237. Directions for the Tanning and Dressing of Furs.

238. The Apricot in California.

239. Harvesting and Handling Apricots and Plums for Eastern Shipment.

240. Harvesting and Handling Pears for Eastern Shipment.

241. Harvesting and Handling Peaches for Eastern Shipment.

243. Marmalade Juice and Jelly Juice from Citrus Fruits.

244 Central Wire Bracing for Fruit Trees.

245. Vine Pruning Systems.

247. Colonization and Rural Development.

248. Some Common Errors in Vine Pruning and Their Remedies.

249. Replacing Missing Vines.

250. Measurement of Irrigation Water on the Farm.

252. Supports for Vines.

253. Vineyard Plans.

254. The Use of Artificial Light to Increase Winter Egg Production.

255. Leguminous Plants as Organic Fertil. izer in California Agriculture.

256. The Control of Wild Morning Glory.

257. The Small-Seeded Horse Bean.

258. Thinning Deciduous Fruits.

25. Pear By-products.

261. Sewing Grain Sacks.

262. Cabbage Growing in California.

263. Tomato Production in California.

264. Preliminary Essentials to Bovine Tuberculosis Control.
No.

265. Plant Disease and Pest Control.

266. Analyzing the Citrus Orchard by Means of Simple Tree Records.

267. The Tendency of Tractors to Rise in Front: Causes and Remedies.

269. An Orchard Brush Burner.

270. A Farm Septic Tank.

272. California Farm Tenancy and Methods of Leasing.

273. Saving the Gophered Citrus Tree.

274. Fusarium Wilt of Tomato and its Control by Means of Resistant Varieties.

276. Home Canning.

277. Head, Cane, and Cordon Pruning of Vines.

278. Olive Pickling in Mediterranean Countries.

279. The Preparation and Refining of Olive Oil in Southern Europe.

281. The Results of a siurvey to Determine the Cost of Producing Beef in California.

282. Prevention of Insect Attack on Stored Grain.

283. Fertilizing Citrus Trees in California.

284. The Almond in California.

285. Sweet Potato. Production in California.

286. Milk Houses for California Dairies.

287. Potato Production in California.

288. Phylloxera Resistant Vineyards.

289. Oak Fungus in Orchard Trees.

290. The Tangier Pea.

291. Blackhead and Other Causes of Loss of Turkeys in California.

292. Alkali Soils.

293. The Basis of Grape Standardization:

294. Propagation of Deciduous Fruits.

295. The Growing and Handling of Head Lettuce in California.

296. Control of the California Ground Squirrel.

298. The Possibilities and Limitations of Coöperative Marketing.

299. Poultry Breeding Records.

300. Coccidiosis of Chickens.

301. Buckeye Poisoning of the Honey Bee.

302. The Sugar Beet in California.

303. A Promising Remedy for Black Measles of the Vine.

304. Drainage on the Farm.

305. Liming the Soil.

306. A General Purpose Soil Auger and its Use on the Farm.

307. American Foulbrood and its Control.

The publications listed above may be had by addressing

College of Agriculture,

University of California,

Berkeley, California. 